\title{
The energy performance contract - key towards energy efficiency in Europe?
}

\author{
Corina MURAFA \\ Corina.Murafa@gmail.com \\ The Bucharest University for Economic Studies, Bucharest, Romania
}

\begin{abstract}
The paper focuses on the Energy Performance Contract (EPC) as a business model for energy efficiency. More precisely, it examines, using two case studies, enablers and disablers - from an economic, legal and institutional/ managerial perspective - for advancing this arrangement across the EU. The EU has set a 20\% energy savings target by 2020 (roughly equivalent to turning off 400 power stations), with an even more ambitious target of $27 \%$ by 2030 . To reach these ambitious targets, the investments needed are approximately EUR $100 \mathrm{bn} /$ year across the EU (according to the European Commission). Energy efficiency is not, as fervent proponents often claim, the low hanging fruit in terms of investment efforts. Like any other sub-sector, such as transmission and distribution, it demands innovative financing instruments to ensure adequate scale-up. In the paper, I use two comparative case studies to identify and classify the disablers and enablers of Energy Performance Contracting/ Energy Services Companies (ESCOs) development: the European frontrunner, namely Germany, and a laggard, namely Romania. As research methodology, I use literature review, comparisons between similar government policy planning and evaluation documents, and stakeholder interviews. While academic literature on the topic (Seefeldt, 2003; Wilhelm, 2015) is developed for Germany, for Romania a critical reflection on EPC promotion policy is to be found only in industry documents (e.g.: ARPEE, 2013; Tractebel, 2015). The German success demonstrates that, contrary to the belief of Romanian stakeholders, it is not the lack of a standardized contract model that prevents EPC development, but lack of genuine commitment, drive and leadership of public officials in promoting this financing instrument. A solid communication between public authorities and private beneficiaries, and public administration capacity for impact assessment and evidence-based policy planning are two other significant enablers of EPCs, that could foster this financing instrument across the EU.
\end{abstract}

Keywords: energy efficiency, energy services, energy performance contract, energy policy, Romania, Germany.

\section{Introduction}

The European Union has set ambitious targets when it comes to reducing energy consumption and attaining a greater degree of energy efficiency. As part of the Europe 2020 Strategy, Member States have agreed to an energy efficiency target of $20 \%$. This general efficiency target was translated in the Energy Efficiency Directive from 2012. According to the burden-sharing principle, Member States were free to choose individual national targets, as long as the general EU-wide target would be reached.

The European Commission is tracing periodically the progress towards this target, through specific reports. The latest such assessment document, launched in November 2015, took note that, according to a Commission evaluation from 2014, the level reached by 2020 would fall below the $20 \%$ by $1-2 \%$. Currently, the national indicative targets of Member States fall short of the collective $20 \%$ by $2.4 \%$ (COM, 2015).

The European Commission, upon analyzing the financing market for energy investment across Europe concluded that "energy efficiency market has strong investment potential, but is still small, fragmented, (deemed) risky, and [...] relies predominantly on direct or indirect subsidies." (COM, 2015). 
Literature points out the immense potential of this financing instrument. Evidence at EU level indicate ESCOs achieve, on average, 16-30\% energy savings (Wilhelm, 2015), but there is an expectation newly initiated EPCs will achieve on average 30\% savings. Regular Energy Performance Contracting (EPC) is particularly suitable for large buildings, while for other energy efficiency and renewables application abridged versions are preferable (Bleyl, 2011. Literature points out that, while developed countries may easily achieve results with regular ESCOs, a government-led so-called "super ESCO" is needed in developing countries, due to weak institutions (Limaye et al., 2015).

Given the context described above, the paper will investigate the potential of Energy Performance Contracting (EPC), as a business model, to become a reliable instrument for triggering the necessary level of energy efficiency investments, in particular in the buildings sector. It will draw on the experience of two countries Romania and Germany - in using this business model. While academic literature on energy efficiency in Germany is abundant, in Romania policy papers by industry bodies or by the national government dominate the landscape. The research branch of the European Commission, the JRC, concludes that while Germany, together with France, UK, and Austria has a large energy services market, Romania has a small one (Economidou M., 2015). Literature on Romania identifies as main causes for lack of policy effectiveness weak inter-institutional cooperation, the fact decision-making is not based on impact studies, and ineffective communication between public authorities, energy companies, and consumers (ARPEE, 2013). With respect to Germany, literature identifies as main enablers that spearheaded Germany as the clear pioneer and frontrunner of the EPC model are public sector initial support - the main initial clients need to be from the public sector; high-quality communication with project beneficiaries; the existence of specialized energy agencies with specific know-how, that can act as mediators between energy efficiency service companies and clients; standardized regulation, including in the public procurement field; the existence of complex interdisciplinary project management skills, to enable clear targets and results (Seefeldt, 2003).

\section{Operationalizing the concepts}

The definition of Energy Performance Contracting (EPC) is, according to the Energy Efficiency Directive 2012/27/EU, the following: "a contractual arrangement between the beneficiary and the provider of an energy efficiency improvement measure, verified and monitored during the whole term of the contract, where investments (work, supply or service) in that measure are paid for in relation to a contractually agreed level of energy efficiency improvement or other agreed energy performance criterion, such as financial savings.

The key principle of such a mechanism is that the loan for the energy efficiency investment is paid back straight out of the saved energy costs and that the energy service company (ESCO) contracted to perform the project guarantees, in one form or another, the results of its work.

The scheme below summarizes the functioning of a classical EPC scheme: 


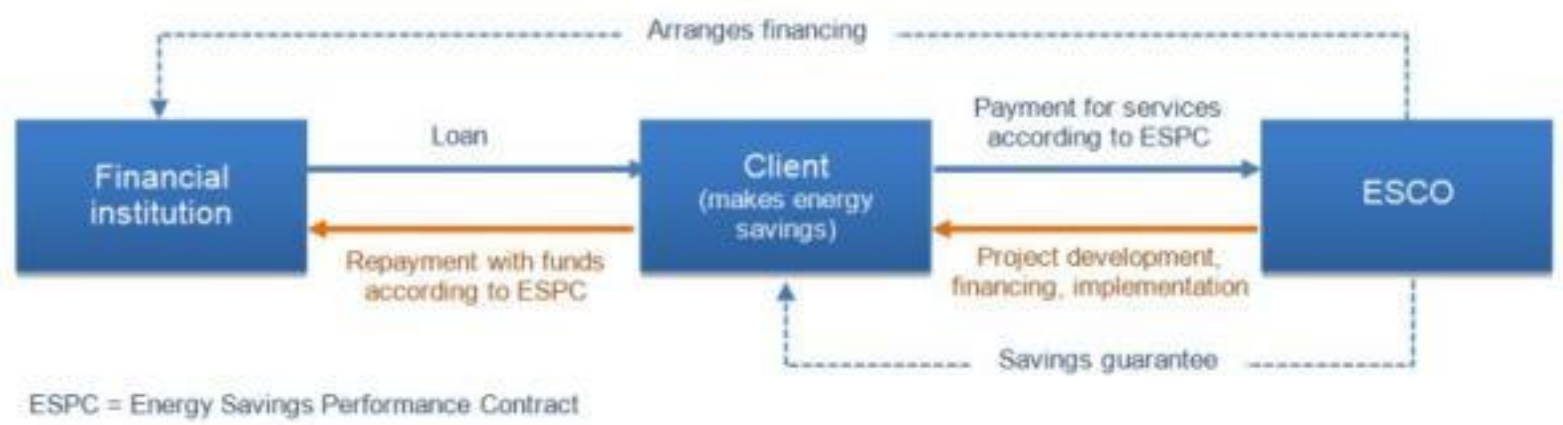

PICBE | 105

Figure 1. Energy Savings Performance Contract: How It Works?

Source: www.seai.ie.

By "enabler" I am referring to capabilities, forces and resources that contribute to the success of the EPC as a business model. By "disabler" I understand the opposite, namely capabilities, forces and resources that contribute to the failure of EPC as a business model.

\section{Research methodology}

The research methodology I chose is a two-case research design, with comparative elements, between two countries that have been the champion, respectively the laggard in the promotion and usage of the energy performance contract - namely Germany and Romania. The impact of this decision is obvious: having exercised successfully access to an effective financing instrument for advancing energy efficiency, Germany chooses both more ambitious energy efficiency targets at EU level and also overachieves them constantly, while Romania chooses less ambitious targets.

The main vectors I will investigate in the comparison will be grouped in so-called enablers and disablers of the energy performance contract as a financing instrument. I will look primarily at the institutional setup in both countries, at public management capacity and at the existing legislative framework. The unit of analysis is at policy/ government level, not at business level, though it would be very relevant if future research also looked at businesses as a unit level for analysis, and surveyed their motivations for engaging or not in such financing arrangements.

\section{Energy efficiency in Romania and Germany: differences in approach based on literature and policy documents surveys}

EU regulations are requesting all Member States to submit thematic policy documents and monitoring thereof in more sub-areas of energy efficiency, which makes a comparison easier. I reviewed the following national documents submitted by Germany and Romania to the EU Commission: their Long Term Renovation Strategies, their National Energy Efficiency Action Plans (NEEAPS), which Member States have to draw up every three years (2014), and the 2016 National Annual Report on the energy efficiency target (a mandatory yearly requirement as per the Energy Efficiency Directive).

While Romania's long-term renovation strategy mentions the main issues with the current residential building stock and that ESCOs will be the primary financing instrument for future renovation works in both private and public buildings, Germany's similar document tracks the impact of actions already undertaken. Thus, while a similar percentage of residential buildings are very old, during 2006 and 2010 Germany ran a renovation programme worth EUR 120 million/ year, with $60 \%$ of the works already 
completed, resulting in energy savings of 300 million kilowatt-hours. In addition, between 1990 and 2012 energy savings of 30\% were also achieved in private buildings, also due to a tax relief system (max. 1200 EUR can be deduced yearly from taxes due, provided renovation work is performed). The German strategy does not mention at all that ESCOs have been or plan to be used in the buildings sector, but instead that federal banks are developing financing instruments, while the Romanian strategy lists the clarification of the legislative framework supporting ESCOs as a national priority (the strategy dating from 2014). However, from Germany's NEEAP it clearly results that ESCOs have been a preferred instrument for attaining energy savings. Thus, the German energy services market is considered as one of the most developed in Europe, characterized by "lively competition". In terms of size, it is estimated to be between EUR 3 and 4 billion (annual revenues), with an average of 13.000 registered energy consulting services. The vast majority of energy contracting is represented by energy supply contracting, meaning a full service delivery of energy to a client (including system design and the supply of energy per se, including savings targets), while only $9 \%$ is purely energy saving contracting. Other sources confirm that "the smallest market segment of the ESCO market in Germany is still the EPC market" (Wilhelm, 2015), but that the market still is the most dynamic in Europe.

Romania's NEEAP mentions that the ESCO arrangement is still unregulated and due to this fact largely underdeveloped in Romania. The report lists several policy implementation targets, such as formulating, in cooperation with EBRD experts, recommendations on improving the legislative framework.

Based on existing policy documents, the main difference in approach between Germany and Romania seems to be the heavy data reliance and constant impact measurement, which seem to drive policy planning in Germany, while the contrary is to be encountered in Romania: much lengthier texts, focusing on descriptions of the current situation, and rather clear, yet not always quantifiable plans for the future. However, there is little trace of impact measurement of existing measures. While there is no mention of plans regarding the promotion of ESCO arrangements in German policy documents, there is a clear tracing of their achieved impact. On the contrary, in Romanian documents they are repeatedly declared a national priority, with the main intended action being the clarification of the legislative framework that concerns these arrangements.

The JRC analyzed all NEEAPs and concluded the German market exceeds $1.6 \mathrm{bn}$ EUR in terms of investment volume, and also has the highest number of projects in the EU (over 200). Interestingly, the JRC concludes neither Romania, nor Germany, compared to other MS, promote any policy support measures (e.g.: legislative measures, financial incentives, information measures, registry of ESPs) for ESCOs. Furthermore, in contrast to other MS (e.g.: Austria, Cyprus, Spain, France, etc.), Germany doesn't have a published EPC model and yet the market is flourishing. My hypothesis is that the comparative analysis performed by the JRC specialists is flawed, as it is based primarily on the non-standardized NEAAPs that MS submit regularly. These documents do not require MS to list the measures applied to support EPCs, so obviously there is a wide difference in approach between them.

Academic literature on the effectiveness and impact of energy efficiency policies in Romania is scarce. Instead, policy documents, issued by either public institutions or private bodies (i.e. industry associations) prevail. The main causes identified by the Romanian Association for the Promotion of Energy Efficiency, ARPEE, for the 
underdeveloped status of the Romanian energy services market are: clients in both the public and private sector lack information on available energy services and on this type of financial instruments and do not trust it; the fact neither public authorities, nor large industrial clients are obliged to implement the energy efficiency measures resulted from the mandatory energy audits; the fact ESCOs are not certified. Lack of communication between ESCOs and potential public sector beneficiaries, alongside lack of know-how and training are also blamed for this state of play (Wilhelm, 2015). Energy performance contracting, in turn, is believed to be underdeveloped because, although mentioned in one law (Emergency Ordinance 22/ 2008), this law is not harmonized with the main fiscal and procurement laws currently in force. Thus, the contract is treated, from a fiscal-budgetary perspective, just as any service contract. The state budget law restricts using public funding for paying utilities, so the payment for energy savings provided by ESCOs cannot be paid as a regular utility payment. The same rules for budgetary prudence restrict the public debt of local municipalities, so they cannot access large energy efficiency projects financed through EPC-like arrangements. Lack of legal clarity is confirmed as being a significant disabler for EPC development by other sources, too (Wilhelm, 2015). As mentioned earlier, despite the fact Romania has been a member in various European EPC-centered research consortia, there is no unified repository of the lessons learnt, neither is there a catalogue of all the EPC-financed projects and their impact. The resulting documents from EnPC-INTRANS research project maintain "no EPC for public buildings has been concluded with local authorities in the country", with the only such project being concluded between the French Embassy and the local subsidiary of Veolia. Other sources circulate different data. It is said that Turda municipality (approx. 50000 inhabitants) has pursued an EPC for public lighting, resulting in savings of 40\% (ARPEE, 2013). Tractebel, an ESCO, discusses about pilot projects in Romanian schools and hospitals, comprising more buildings in the same project, with an average energy consumption of $1500-5000 \mathrm{MWh} /$ year, and with an estimated investment volume of 500000 - 1500000 EUR. They do not mention however the impact of these projects (Tractebel, 2015).

On the contrary, academic literature on these topics with regards to the German market is quite telling. Seefeldt (2003), giving the examples of the Berlin Energy Saving Partnership, in which 750 public buildings were bundled up in 11 EPCs, resulting in significant economies of scale and energy savings is that a visible start signal, that creates demand for EPCs, is essential. However, Seefeldt examines other case studies (e.g.: Austria, Slovenia) and claims that standardization is not at all the biggest obstacle, but instead it would be the people who do not buy into this agenda. On the contrary, other studies based on stakeholder interviews concluded that lack of standardized contracts accepted by all public authorities leads to high transaction costs and thus acts as an EPC disabler (Wilhelm, 2015). Coupling Seefeldt's conclusions with my own hypothesis on the comparative JRC analysis (see above) it would seem indeed that standardization is not the main driver behind the success or failure of EPCs. According to a study performed by Prognos AG et. al in 2013 for the Federal Energy Efficiency Center (BfEE), the main disabler for further EPC contracting in Germany are restrictions in tennancy law, disadvantages in support programmes and legal barriers in the public sector. According to contractors the small number of tendered projects, complex procedures and high sales efforts, coupled with the bad reputation of the EPC model act as disablers to this financing instruments; at the same time, beneficiaries see legal procedures as being too cumbersome, as they are requested to prove that the EPC model 
is less costly than traditional financing of energy efficiency works, despite the fact this has proven to the be case time and again (Wilhelm, 2015). Long-term contractual bonds, lack of trust in resulting benefits, and lack of publicity are considered to be least significant disablers (BfEE, 2015).

\section{Results}

From analyzing existing literature and policy documents, as well as based on several expert interviews conducted in Romania, the results of the comparative case studies analyzed in this paper - Romania and Germany - are the following. From the perspective of the clarity and maturity of the legislative framework, it became clear that in Romania lack of legal clarity is perceived as the greatest obstacle towards the wide roll-out of EPCs. On the other hand, while it is clear that the German EPC market enjoys much greater maturity of the governing legislative framework, neither academic literature, nor policy documents perceive this as being the greatest enabler of EPC success. On the contrary, just as Romania, Germany does not have a standardized EPC model, unlike ten other EU Member States (JRC, 2015), and still is the absolute champion both in terms of EPC/ ESCO market size, and also variety of players. The administrative capacity of public authorities involved in promoting EPCs in the two countries examined has been measured through both the quality and comprehension of policy documents, but also through stakeholder interviews. Literature points out that the German success is indeed based to a great extent on the existence of a professional specialized agency with specialized know-how, that can promote this new business model to potential beneficiaries. Stakeholders interviewed in Romania from the private sector (ESCOs, financial institutions) claim that the administrative capacity of public authorities is indeed low, while this is not pointed out in official documents evidencing the setup for energy efficiency policy. Constant and high quality communication between public bodies and private beneficiaries is seen in Germany as a significant enabler of the EPC success, while in Romania industry points out this is one of the main points that needs significant improvement. The scattered institutional setup in Germany is largely due to the federal character of the country, with many project promoters being regional governments, for instance. In Romania energy efficiency is very often mentioned as a policy priority, yet the government does not seem to follow through on these commitments, with little capacity and direction for steering energy efficiency policies in line ministries. Although stakeholders mention and industry also defends the position that a distinct government agency dealing with energy efficiency should be created, the German examples points out this is not necessarily the prerequisite for success. Instead, the German case shows that a much more significant enables is leadership of public officials and their real buy-in into the energy efficiency agenda. This drives both the public sector to act as a first mover/ a role model in EPC contracting, to more ambitious savings target and to a culture of energy efficiency. Indeed, the Romanian case points out that the lack of agency of public officials - a point in case is that the same "main cause" is listed for five years in a row as the main culprit for the lack of ESCO/ EPC development, with no progress on this very concrete target pushed by any official - is a significant disabler of EPC roll out. The table below summarizes the findings for the two countries.

Table 1. Summary findings of EPC enablers and disablers in Germany and Romania

\begin{tabular}{|l|lll|l|l|}
\hline Enablers/disablers & Germany & & Romania & \\
\hline clarity and maturity of the & Also no standardized & EPC & No standardized EPC model. \\
\hline
\end{tabular}




\begin{tabular}{|c|c|c|}
\hline legislative framework & $\begin{array}{l}\text { model, but no deterrent for the } \\
\text { market development. Minor } \\
\text { other obstacles (e.g.: lack of } \\
\text { clarity in tenancy law). }\end{array}$ & $\begin{array}{l}\text { Despite being pointed out by } \\
\text { interviewees and policy } \\
\text { documents as the most } \\
\text { significant disabler, comparative } \\
\text { evidence from Germany } \\
\text { indicates it shouldn't be } \\
\text { regarded as such a crucial factor. }\end{array}$ \\
\hline $\begin{array}{l}\text { the administrative capacity of } \\
\text { public authorities involved in } \\
\text { promoting such financing } \\
\text { arrangements }\end{array}$ & $\begin{array}{l}\text { Very high, based on impact } \\
\text { assessment and quantifying } \\
\text { achieved results. }\end{array}$ & $\begin{array}{l}\text { Low. Lengthy policy documents } \\
\text { fail in taking critical stock of } \\
\text { achieved results, focusing } \\
\text { instead on "promised targets" } \\
\text { for the future. Interviewees also } \\
\text { point out institutional } \\
\text { fragmentation and weak } \\
\text { institutional capacity. }\end{array}$ \\
\hline the institutional setup & $\begin{array}{l}\text { Fragmented (regional character } \\
\text { of the country), but government } \\
\text { agencies display high technical } \\
\text { know-how and are able to } \\
\text { communicated intensively with } \\
\text { potential beneficiaries. Public } \\
\text { sector acting as original buyer of } \\
\text { ESCO services, to stimulate } \\
\text { demand. }\end{array}$ & $\begin{array}{l}\text { Fragmented, with co-ownership } \\
\text { ministry and regulator. } \\
\text { Incapable of fostering } \\
\text { communication with owners. }\end{array}$ \\
\hline $\begin{array}{l}\text { the leadership/ agency of } \\
\text { public officials }\end{array}$ & $\begin{array}{l}\text { Highest enabler. Berlin case } \\
\text { with municipality acting as } \\
\text { largest owner and supporter of } \\
\text { EPCs point in case. }\end{array}$ & $\begin{array}{l}\text { Highest disabler. Political } \\
\text { statements not matched by real } \\
\text { ambitions, result. Point in case: } \\
\text { for over five years authorities } \\
\text { not able to finalize a draft EPC } \\
\text { model. }\end{array}$ \\
\hline
\end{tabular}

Source: own conclusions.

\section{Conclusions}

Policy makers need to pay special attention to avoiding pitfalls, while focusing on important enablers for the promotion of this model. Evidence shows, beyond doubt, that this instrument works, achieves average savings of 30\%, and is much cheaper for the beneficiary than traditional loans for energy efficiency works. However, the complexity of this instrument, including legal barriers, is significant even in advanced countries, like Germany. However, it is not, contrary to the position of Romanian authorities, the lack of a standardized EPC contract that prevents market development, but rather lack of genuine commitment, drive and leadership of public officials in promoting this channel. The German case, for instance the achievements of the Berlin Energy Agency, shows that it is crucial for the public sector to be strong-willed and act as a role model in contracting energy efficiency services financed through an EPC-like arrangement. Last but probably most important, one of the clear differences in the German and Romanian approaches, that can explain the success of EPC development in Germany, in contrast to Romania, is the capacity of the public administration to trace regularly and professionally the impact of certain policies for EPC promotion, and to focus in policy planning not just on setting targets, but especially on measuring the progress attained so far. 


\section{References}

Asociația Română pentru Promovarea Eficienței Energetice (ARPEE) (2013), Eficiența Energetică în România. Cartea Albă, Editura AGIR.

BfEE (Presenter, Jonas Geissler) (2015), Energy Performance Contracting in Germany. The role of facilitators for the market, available at www.esd-ca.eu/privatearea/.../energy.../energy-performance-contracting-germany (last accessed 3 PICBE|110 March 2017).

Bleyl, J.W. (2011), Conservation first! The new integrated energy-contracting model to combine energy efficiency and renewable supply in large buildings and industry. ECEEE 2011 Summer Studies, paper ID 485.

DIRECTIVE 2012/27/EU OF THE EUROPEAN PARLIAMENT AND OF THE COUNCIL of 25 October 2012 on energy efficiency, amending Directives 2009/125/EC and 2010/30/EU and repealing Directives 2004/8/EC and 2006/32/EC, available at http://eurlex.europa.eu/LexUriServ/LexUriServ.do?uri=0J:L:2012:315:0001:0056:EN:PDF (last accessed 21 February 2016).

DG Energy webpage on energy efficiency financing, https://ec.europa.eu/energy/en/top ics/energy-efficiency/financing-energy-efficiency (last accessed 31 October 2016).

DG Joint Research Center webpage on energy service companies, http://iet.jrc.ec.europa.eu/energyefficiency/esco (last accessed 12 January 2017)

Economidou, M., Joint Research Center (2015), Energy Services Market in the EU Workshop. An EU Overview, available online at http://iet.jrc.ec.europa.eu/energy efficiency/sites/energyefficiency/files/events/Energy-Services-Market-in-theEU/2_esm_slides_economidou.pdf (last accessed 3 March 2017).

European Commission, 2015, COM(2015) 574 final, Assessment of the progress made by Member States towards the national energy efficiency targets for 2020 and towards the implementation of the Energy Efficiency Directive 2012/27/EU as required by Article 24 (3) of Energy Efficiency Directive 2012/27/EU, available at https://ec.europa.eu/energy/sites/ener/files/documents/1_EEprogress_report. pdf (last accessed 21 February 2016).

Wilhelm, B. (2015), EnpC-INTRANS: Baseline study on the current state of EPC/ ESCO project development and implementation in the public sector in partner countries, Deliverable no 6.1 in the project "EnPC-Intrans Capacity Building on Energy Performance Contracting in European Markets in Transition", available at www.enpc-intrans.eu/wp-content/uploads/2015/07/EnPC-INTRANS-D6-1Final.pdf_last accessed 4 March 2017).

Limaye, D. R., \& Limaye, E. S. (2011), "Scaling up energy efficiency: the case for a Super ESCO", in Energy Efficiency, 4(2), 133-144.

Seefeldt, F. (2003), "Energy performance: Success in Austria and Germany - Dead End for Europe", in eceee 2003 Summer Study proceedings, ISBN: 91-631-4001-2, available at http://www.eceee.org/library/conference_proceedings/eceee_Sum mer_Studies/2003c (last accessed 12 January 2017).

Tractebel Engineering GDF Suez, Bogdan Anton - Energy Efficiency Department (2015), Contractul de Performanță Energetică. Proiecte pilot în municipalități, available online at www.anre.ro (last accesed 3 March 2017). 